\section{Increased Efficiency of Binding of Nascent C3b to the Erythrocytes of Chronic Cold Agglutinin Disease}

C. J. Parker, C. M. Soldato, and M. J. Telen

Department of Medicine and the Myrtle Bell Lane Laboratory, Duke University Medical Center, Durham, North Carolina 27710 bstract. The pathogenesis of chronic cold agglutinin disease (CCAD) has been enigmatic. To determine if abnormal erythrocyte membrane constituents might provide the stimulus for antibody production, we compared the electrophoretic pattern of radiolabeled membrane glycoproteins of four patients with CCAD to that of normal control erythrocytes. For the CCAD erythrocytes, fluorographs revealed the appearance of an abnormal band whose molecular weight was estimated at $126,000 \mathrm{D}$. Using two-dimensional gel analysis and immunoblotting techniques, it was determined that the $126,000 \mathrm{D}$ glycoprotein consisted predominately of polymeric glycophorin- $\alpha$. Previous investigations had suggested that abnormalities in glycophorin- $\alpha$ influence the functional activity of the complement system. When purified complement (C)3 was activated in the fluidphase by cobra venom factor complexes, CCAD erythrocytes bound nascent $\mathrm{C} 3 \mathrm{~b}$ 7-27 times more efficiently than normal erythrocytes. Normal erythrocytes could be induced to manifest the appearance of the 126,000 $D$ band, and the increased efficiency of binding of nascent $\mathrm{C} 3 \mathrm{~b}$ by incubation with CCAD serum or with the purified cold agglutinin antibody plus autologous serum, but not with the purified antibody alone or the purified antibody plus EDTA-chelated autologous serum. These studies demonstrate that the interactions of IgM cold-reacting antibody and complement with glycophorin induce changes in the biophysical properties of the erythrocyte membrane which modify subsequent interactions with complement.

Parts of this work were presented to the American Society of Hematology, 3-6 December 1983, San Francisco, CA.

Address correspondence to Dr. Parker, Medical Service, Veterans Administration Medical Center, Salt Lake City, UT 84148.

Received for publication 30 December 1983 and in revised form 10 May 1984

J. Clin. Invest.

(c) The American Society for Clinical Investigation, Inc. 0021-9738/84/09/1050/13 $\$ 1.00$

Volume 74, September 1984, 1050-1062

\section{Introduction}

Chronic cold agglutinin disease (CCAD) ${ }^{1}$ is an autoimmune hemolytic anemia characterized by the production of a monoclonal IgM antibody (almost invariably IgM kappa) which reacts optimally at temperatures below $37^{\circ} \mathrm{C}$ with determinants of the I-antigen system of human erythrocytes $(1,2)$. The pathogenesis of the disease has been enigmatic. Whether the chronic production of the antibody is the manifestation of an immunoregulatory defect, a neoplastic process, or a physiological response to a stimulus has never been clearly defined. Since antigenic determinants of the I-system are associated with the carbohydrate moiety of the major erythrocyte sialoglycoprotein, glycophorin- $\alpha^{2}(1,2)$, we compared the glycoproteins of CCAD erythrocytes with those of normal erythrocytes to determine if abnormal membrane constituents might provide

1. Abbreviations used in this paper: $5 \mathrm{P}(8) \mathrm{BS}-\mathrm{PE}$, phosphate-buffered saline containing $150 \mathrm{mM}$ sodium chloride, $5 \mathrm{mM}$ sodium phosphate, $1 \mathrm{mM}$ PMSF, and $1 \mathrm{mM}$ EDTA, $\mathrm{pH} 8.0$; 5P(8)-PE, $5 \mathrm{mM}$ sodium phosphate containing $1 \mathrm{mM}$ PMSF and $1 \mathrm{mM}$ EDTA, pH 8.0; C, complement; CCAD, chronic cold agglutinin disease; CoF, cobra venom factor; CoFBb, activated cobra venom factor complexes; CR1, human erythrocyte receptor for $\mathrm{C} 3 \mathrm{~b} ; \mathrm{E}^{*} \mathrm{C} 3$, radiolabeled erythrocytes bearing nonspecifically bound $\mathrm{C} 3 ; \mathrm{E}^{*} \mathrm{C} 3 \mathrm{~b}$, radiolabeled erythrocytes bearing $\mathrm{C} 3 \mathrm{~b}$; $\mathrm{Ep}^{*} \mathrm{C} 3^{*}$, erythrocytes bearing nonspecifically bound $\mathrm{C} 3$ subsequently radiolabeled using $\mathrm{NaIO}_{4}$ and $\mathrm{NaB}^{3} \mathrm{H}_{4} ; \mathrm{Ep}^{*} \mathrm{C} 3 \mathrm{~b}^{*}$, erythrocytes bearing $\mathrm{C} 3 \mathrm{~b}$ subsequently radiolabeled using $\mathrm{NaIO}_{4}$ and $\mathrm{NaB}^{3} \mathrm{H}_{4}$; EC $3^{*}$, erythrocytes bearing nonspecifically bound radiolabeled $\mathrm{C} 3$; EC3b*, erythrocytes bearing radiolabeled C3b; $\mathrm{GP}_{\mathrm{ca}}, 126,000 \mathrm{D}$ glycoprotein associated with CCAD; GVB, VBS containing $0.1 \%$ gelatin; $\mathrm{GVB}^{+}, \mathrm{GVB}$ containing $5 \mathrm{mM}$ magnesium; $\mathrm{GVB}^{++}$, GVB containing $1 \%$ bovine serum albumin; GVB-EDTA, GVB containing $15 \mathrm{mM}$ EDTA; $\mathrm{NaB}^{3} \mathrm{H}_{4}$, tritiated sodium borohydride; $\mathrm{NaIO}_{4}$, sodium metaperiodate; PMSF, phenylmethylsulfonyl fluoride; PNH, paroxysmal nocturnal hemoglobinuria; SDS-PAGE, sodium dodecyl sulfate-polyacrylamide gel electrophoresis; VBS, veronal-buffered saline.

2. A modification of the nomenclature of Anstee and Furthmayr is used to describe the major erythrocyte sialoglycoproteins (13). Glycophorin, from Furthmayr's nomenclature, is the general term used when referring to these sialoglycoproteins, while the Greek symbols from Anstee's nomenclature are used to denote the glycophorin subspecies. When comparing the nomenclature of Anstee with that of Furthmayr: $\alpha=\mathrm{A} ; \beta=\mathrm{C} ; \gamma=\mathrm{C} ; \delta=\mathrm{B}$. When comparing Steck's nomenclature with that of Anstee: PAS $1=\alpha_{2}$ ( $\alpha$-homodimer); PAS $2=\alpha$; PAS 2 $=\beta ;$ PAS $3=\delta ;$ PAS $4=\alpha \delta(\alpha \delta$-heterodimer $)$. 
the stimulus for antibody production. These investigations demonstrated an abnormal membrane glycoprotein (GP associated with the CCAD erythrocytes. In addition, CCAD erythrocytes were found to bind 7-27 times more fluid-phase activated complement (C)3b than normal erythrocytes, and this greater efficiency of binding of nascent $\mathrm{C} 3 \mathrm{~b}$ appeared to be a consequence of the presence of $\mathrm{GP}_{\mathrm{ca}}$. The acquisition of $\mathrm{GP}_{\mathrm{ca}}$, however, is an epiphenomenon resulting from the interactions of the IgM cold agglutinin and complement with erythrocyte membrane glycoproteins. This appears to be the first instance in which antibody and complement reacting with cell surface constituents has been demonstrated to induce changes in the intrinsic biochemical/biophysical properties of the membrane, and thereby, to render subsequent interactions with complement aberrant. Because these changes occur in vivo, they may be implicated in the pathophysiological manifestations of CCAD.

\section{Methods}

Buffers. The following buffers were employed: Veronal-buffered saline, pH 7.5 (VBS); VBS containing $0.1 \%$ gelatin (GVB); GVB containing $5 \mathrm{mM}$ magnesium $\left(\mathrm{GVB}^{+}\right)$; GVB containing $0.15 \mathrm{mM}$ calcium and $0.5 \mathrm{mM}$ magnesium $\left(\mathrm{GVB}^{++}\right)$; GVB containing $1 \%$ bovine serum albumin (BSA) (Sigma Chemical Co., St. Louis, MO); GVB containing $15 \mathrm{mM}$ EDTA (Sigma Chemical Co.) (GVB-EDTA); $3.5 \mathrm{mM}$ veronal buffer containing $10 \mathrm{mM}$ sodium chloride, $1 \%$ BSA, $3.5 \%$ dextrose, $0.2 \%$ sodium azide, and $20 \mathrm{mM}$ EDTA; Alsever's solution (3); phosphate-buffered saline (PBS) containing $150 \mathrm{mM}$ sodium chloride and $10 \mathrm{mM}$ sodium phosphate, pH 7.4 (PBS); PBS containing $150 \mathrm{mM}$ sodium chloride, $5 \mathrm{mM}$ sodium phosphate, $1 \mathrm{mM}$ phenylmethylsulfonyl fluoride (PMSF) (Sigma Chemical Co.), and 1 mM EDTA, pH 8.0 [5P(8)BS-PE]; $5 \mathrm{mM}$ sodium phosphate containing $1 \mathrm{mM}$ PMSF and 1 mM EDTA, pH 8.0 [5P(8)-PE].

Human erythrocytes, plasma, and serum. Erythrocytes from normal donors or from patients with CCAD were drawn under sterile conditions using EDTA as an anticoagulant. The erythrocytes were pelleted and the plasma was aspirated and frozen at $-90^{\circ} \mathrm{C}$. Then, the erythrocytes were washed in GVB-EDTA which had been prewarmed to $37^{\circ} \mathrm{C}$. After the third wash, the supernate was aspirated as completely as possible and the erythrocytes were stored at $4^{\circ} \mathrm{C}$ in an equal volume of Alsever's solution. Serum from normal donors or from patients with CCAD was obtained by allowing blood to clot at $37^{\circ} \mathrm{C}$. After clot retraction occurred, the supernate was recovered and frozen at $-90^{\circ} \mathrm{C}$.

Cold agglutinin titers. Agglutination tests to determine I-antigen specificity were performed by simultaneously incubating $50 \mu l$ of $\mathrm{O}^{+}$ adult erythrocytes $\left(2.2 \times 10^{8} / \mathrm{ml}\right)$ or $50 \mu \mathrm{l}$ of $\mathrm{O}^{+}$fetal erythrocytes (cord cells) $\left(2.2 \times 10^{8} / \mathrm{ml}\right)$ with twofold falling dilutions of an equal volume of EDTA-chelated plasma for $4 \mathrm{~h}$ at $4^{\circ} \mathrm{C}$. Agglutination was scored from 4+ (complete) to trace (barely visible to the unaided eye). The titer is the greatest dilution showing trace agglutination.

Purification of cold agglutinin. The antibodies were purified by sequential adsorption and elution from normal erythrocytes as previously described (4). The immunoglobulin class of the purified antibody was determined using immunoelectrophoresis and antibodies specific for IgG, IgM, and kappa and lambda light chains.

Complement components. $\mathrm{C} 3$, factor $\mathrm{B}$, and cobra venom factor (CoF) (5) were purified to apparent homogeneity as assessed by sodium dodecyl-sulfate-polyacrylamide gel electrophoresis (SDS-PAGE) (3). Functionally purified factor $\mathbf{D}$ was prepared as previously described (3).

Antibodies. Monoclonal antibodies specific for C3dg (6-9) and the human erythrocyte receptor for C3b (CR1) (10) were the kind gifts of Dr. Gordon D. Ross (University of North Carolina, Chapel Hill, NC). These antibodies were purified from the ascites using 5\% caprylic acid (Sigma Chemical Co.) (9). Monoclonal antibodies against C3c and human IgG were purchased as ascites fluid from Bethesda Research Laboratories (Gaithersberg, MD). The anti-C3c was purified as described (3), while the anti-IgG was purified using 5\% caprylic acid (9). Affinitypurified goat anti-human IgM was purchased from Tago, Inc. (Burlingame, CA). The anti-glycophorin antibody is a murine monoclonal antibody which recognizes an epitope common to all glycophorin species (11). The ${ }^{125}$ I-labeled affinity-purified sheep $F\left(a b^{\prime}\right)_{2}$ anti-mouse, and anti-rat IgG were purchased from Amersham Corp. (Arlington Heights, IL).

Radiolabeling with ${ }^{125} I$. C3, anti-C3c, anti-C3dg, anti-CR1, antiIgG, and anti-IgM were trace labeled with ${ }^{125} \mathrm{I}$ as $\mathrm{NaI}$ (Amersham Corp.) using IODO-GEN (Pierce Chemical Co., Rockford, IL) as previously described (5).

Surface labeling of CCAD and normal erythrocytes with ${ }^{125}$ I was accomplished using IODO-GEN exactly as described by Markwell and Fox (12).

Determination of cell-bound C3c, C3dg, CRI, IgG, and IgM. The amount of radiolabeled antibody used in each of the assay systems was in excess as determined by saturation binding studies.

Using ${ }^{125} \mathrm{I}$-anti-C3c (5), ${ }^{125} \mathrm{I}$-anti-C3dg (8), and ${ }^{125} \mathrm{I}$-anti-CR 1 (10), the amount of erythrocyte bound $\mathrm{C} 3 \mathrm{c}, \mathrm{C} 3 \mathrm{dg}$, and the number of erythrocyte $\mathrm{CR} 1$ sites were determined as previously described.

To assess cell-bound IgG, erythrocytes were washed three times in GVB-EDTA and resuspended to $5 \times 10^{8}$. In quintuplicate, $25 \mu \mathrm{l}$ of cells and $25 \mu \mathrm{l}$ of ${ }^{125} \mathrm{I}$-anti-IgG $(10 \mu \mathrm{g} / \mathrm{ml})$ were incubated for $30 \mathrm{~min}$ at $37^{\circ} \mathrm{C} .40 \mu \mathrm{l}$ were aspirated from each reaction mixture, and bound from unbound ligand was separated as previously described (5). The amount of ${ }^{125} \mathrm{I}$-anti-IgG bound to each cell type was determined, and the mean and standard deviation of each set of quintuplicates was calculated. The amount of radiolabeled ligand bound to CCAD erythrocytes or to normal erythrocytes incubated with CCAD serum (test erythrocytes) was compared with normal control erythrocytes. If there was no statistically significant difference $(P>0.1)$ between the amount of ${ }^{125} \mathrm{I}$-anti-IgG bound to the test erythrocytes compared with the control erythrocytes, then the test erythrocytes are listed as negative.

To determine cell-bound IgM, erythrocytes were washed three times in GVB-EDTA and resuspended to $1 \times 10^{9} / \mathrm{ml}$. In quintuplicate, $10 \mu \mathrm{l}$ of cells were incubated with $10 \mu \mathrm{l}$ of ${ }^{125} \mathrm{I}$-anti-IgM $(20 \mu \mathrm{g} / \mathrm{ml})$ in a final volume of $50 \mu \mathrm{l}$ of GVB-EDTA. To control for nonspecific binding of the radiolabeled ligand, the above experiment was performed simultaneously in the presence of a $50 \mathrm{M}$ excess of unlabeled antiIgM. After incubation for $30 \mathrm{~min}$ at $37^{\circ} \mathrm{C}$, a $40-\mu \mathrm{l}$ aliquot was aspirated from each reaction mixture and bound from unbound ligand was separated as previously described (5). The amount of radiolabeled ligand bound to each cell-type in the presence and absence of unlabeled ligand was determined, and the mean and standard deviation of each set of quintuplicates was calculated. If there was no statistically significant difference $(P>0.1)$ between the amount of ${ }^{125}$ I-anti-IgM bound in the absence of unlabeled anti-IgM as compared with binding in the presence of unlabeled ligand, then the cell-bound IgM was designated as negative.

$S D S-P A G E$ of CCAD and normal erythrocytes labeled with sodium 
meta-periodate ( $\left.\mathrm{NaIO}_{4}\right)$ /tritiated sodium borohydride ( $\mathrm{NaB}^{3} \mathrm{H}_{4}$ ). These procedures were performed using the methods which are described in detail in reference 13.

Efficiency of binding of fluid-phase activated $C 3 b$ to normal and CCAD erythrocytes. Normal and CCAD erythrocytes were washed three times in GVB-EDTA and resuspended to $1 \times 10^{9} / \mathrm{ml}$. Activated cobra venom factor complexes (CoFBb) were prepared by incubating $300 \mu \mathrm{l}$ of cobra venom factor (CoF) $(1.02 \mathrm{mg} / \mathrm{ml}), 300 \mu \mathrm{l}$ of factor $B$ $(1.0 \mathrm{mg} / \mathrm{ml}), 120 \mu \mathrm{l}$ of functionally purified factor $\mathrm{D}$, and $165 \mu \mathrm{l}$ of $\mathrm{GVB}^{+}$. After $30 \mathrm{~min}$ at $37^{\circ} \mathrm{C}, 45 \mu 1$ of $0.2 \mathrm{M}$ EDTA, pH 7.5, were added, and the incubation was continued for $5 \mathrm{~min}$. In triplicate, 1 $\mathrm{ml}$ of normal and CCAD erythrocytes $\left(1 \times 10^{9} \mathrm{ml}\right)$ were pelleted and the supernate was aspirated as completely as possible. $155 \mu \mathrm{l}$ of $\mathrm{CoFBb}$ complexes and $100 \mu l(10 \mathrm{mg} / \mathrm{ml})$ of $\mathrm{C} 3$ was added to each pellet. The suspension was incubated for $30 \mathrm{~min}$ at $37^{\circ} \mathrm{C}$. The erythrocytes were pelleted, and $100 \mu \mathrm{l}$ of supernate was removed for determination of conversion of $\mathrm{C} 3$ to $\mathrm{C} 3 \mathrm{~b}$ by crossed immunoelectrophoresis (3). The cells were washed three times in GVB-EDTA prior to determination of cell-bound C3b, using ${ }^{125} \mathrm{I}$-anti-C3c (5). Controls in these experiments were normal and CCAD erythrocytes which were exposed to $\mathrm{C} 3$ in the absence of $\mathrm{CoFBb}$ complexes.

Preparation of normal and CCAD erythrocytes bearing ${ }^{125} I-C 3 b$. $500 \mu \mathrm{l}$ of packed normal and CCAD erythrocytes which had been washed three times in GVB-EDTA were incubated for $30 \mathrm{~min}$ at $37^{\circ} \mathrm{C}$ with $290 \mu \mathrm{l}$ of CoFBb complexes and $200 \mu \mathrm{l}$ of ${ }^{125} \mathrm{I}-\mathrm{C} 3(10 \mathrm{mg} / \mathrm{ml}$; $\left.3.07 \times 10^{5} \mathrm{cpm} / \mu \mathrm{g}\right)$. The reaction mixtures were spun, and $200 \mu \mathrm{l}$ of supernate was aspirated. The cells (designated $\mathrm{EC} 3 \mathrm{~b}^{*}$ ) were then washed three times in 5P(8)BS-PE and ghosts were prepared as described above. Controls in these experiments were normal and CCAD erythrocytes incubated with ${ }^{125} \mathrm{I}-\mathrm{C} 3$ in the absence of $\mathrm{CoFBb}$ complexes (designated EC3*). After determining protein concentration, the specific activity was calculated by counting $10-\mu l$ aliquots of each sample in a gamma counter. The ghost proteins and supernates were then subjected to SDS-PAGE as described (13). Autoradiographs were prepared by exposing the dried gels to Kodak XAR-5 film (Eastman Kodak Co., Rochester, NY) and storing them at $-90^{\circ} \mathrm{C}$ until developed.

Treatment of CCAD EC3b with hydroxylamine. This procedure was performed using a modification (13) of the method of Law and Levine $(14,15)$. The same method was employed to produce the hydroxylamine-treated normal and CCAD erythrocytes used in the immunoblotting experiments described below.

Preparation of radiolabeled CCAD erythrocytes bearing $C 3 b .4 \mathrm{ml}$ of CCAD erythrocytes $\left(1 \times 10^{9} / \mathrm{ml}\right)$ were radiolabeled with ${ }^{125} \mathrm{I}$ as described above. The cells were washed three times in GVB-EDTA and divided into two equal aliquots. The cells were spun, and the supernate was aspirated as completely as possible. To one aliquot was added $290 \mu \mathrm{l}$ of CoFBb complexes and $200 \mu \mathrm{l}$ of C3 $(10 \mathrm{mg} / \mathrm{ml})$. To the other aliquot, which served as the control, was added $290 \mu \mathrm{l}$ of GVB-EDTA and $200 \mu \mathrm{l}$ of $\mathrm{C} 3(10 \mathrm{mg} / \mathrm{ml})$. The reaction mixtures were incubated for $30 \mathrm{~min}$ at $37^{\circ} \mathrm{C}$, and then washed three times in 5P(8)BS-PE. Ghost cells were prepared as previously described (13). Specific activity was determined, and the ghost were subjected to SDSPAGE. After staining and destaining, autoradiographs were prepared.

Electrophoresis in the second dimension, after treatment of the tracks of interest with hydroxylamine, was performed as previously described (13).

Preparation of CCAD erythrocytes bearing C3b subsequently labeled with $\mathrm{NaIO}_{4} / \mathrm{NaB}^{3} \mathrm{H}_{4} .500 \mu \mathrm{l}$ of packed CCAD erythrocytes which had been washed three times in GVB-EDTA were incubated with $290 \mu$ l of $\mathrm{CoFBb}$ complexes and $200 \mu \mathrm{l}$ of $\mathrm{C} 3(10 \mathrm{mg} / \mathrm{ml})$ for $30 \mathrm{~min}$ at $37^{\circ} \mathrm{C}$ (controls were CCAD erythrocytes incubated with $\mathrm{C} 3$ in the absence of $\mathrm{CoFBb}$ complexes). The cells were washed once in GVB-EDTA and twice in PBS and radiolabeled using $\mathrm{NaIO}_{4} / \mathrm{NaB}^{3} \mathrm{H}_{4}$ as previously described (13). The radiolabeled ghost were then subjected to SDSPAGE under reducing conditions, and fluorographs were prepared (13).

Electrophoretic blotting of normal and CCAD erythrocyte membrane proteins with subsequent immune fixation with monoclonal anti-C3dg and anti-glycophorin. This procedure was performed according to the method of Towbin et al. (16). Briefly, $50 \mu \mathrm{g}$ of hydroxylamine treated or untreated normal and CCAD ghost proteins were subjected to SDSPAGE under reducing conditions. The proteins were then transferred to nitrocellulose paper (Bio-Rad Laboratories, Richmond, CA) over a 4-h period using a Trans-Blot system (Bio-Rad Laboratories). The nitrocellulose paper was incubated overnight at $4^{\circ} \mathrm{C}$ with $10 \mathrm{mM}$ Trisbuffered saline, pH 7.4 (Tris- $\mathrm{NaCl}$ ), containing 3\% BSA. The paper was then cut into two parts with each part containing tracks identical to those of the other. One part was incubated with an appropriate dilution (based on saturation binding studies) of either anti-C3dg (in the form of purified rat $\operatorname{IgG}$ ) or anti-glycophorin (in the form of mouse ascites). The other part of the paper was incubated with either nonimmune rat $\operatorname{IgG}$ or nonimmune mouse ascites to serve as the control in the appropriate experiment. After $2 \mathrm{~h}$ at RT, the nitrocellulose paper was extensively washed in Tris- $\mathrm{NaCl}$. Each half of the paper was then incubated with ${ }^{125}$ I-labeled affinity-purified sheep $\mathrm{F}\left(\mathrm{ab}^{\prime}\right)_{2}$ antimouse IgG (for experiments involving the anti-glycophorin antibody) or anti-rat IgG (for experiments involving the anti-C3dg antibody) for 30 min at RT. The strips were then extensively washed. After drying, autoradiographs were prepared by exposing the strips to $x$-ray film as described above. Molecular weight markers were ${ }^{14} \mathrm{C}$-labeled myosin $(200,000)$, phosphorylase $b(92,500)$, BSA $(69,000)$, ovalalbumin $(46,000)$, carbonic anhydrase $(30,000)$, and lysozyme $(14,300)$ (Amersham Corp.).

Preparation of normal erythrocytes exposed to CCAD serum, purified antibody, and purified antibody plus autologous serum. Erythrocytes from a normal $\mathrm{O}^{+}$donor were washed three times in $\mathrm{GVB}^{++}$. To one aliquot of $1 \mathrm{ml}$ of packed cells was added $3 \mathrm{ml}$ of CCAD serum. To another aliquot was added $3 \mathrm{ml}$ of serum from a normal donor of the same blood type as the patient with $\operatorname{CCAD}\left(\mathrm{A}^{+}\right)$. The reaction mixtures were incubated for $30 \mathrm{~min}$ at $30^{\circ} \mathrm{C}$, then for $60 \mathrm{~min}$ at $37^{\circ} \mathrm{C}$. The cells were washed three times in GVB-EDTA (which had been prewarmed to $37^{\circ} \mathrm{C}$ ) and resuspended to $4 \mathrm{ml}$ in the same buffer. $2 \mathrm{ml}$ were aspirated from each set for determination of cell-bound IgM, IgG, C3c, C3dg, CR1 sites/cell, and efficiency of binding of fluidphase-activated $\mathrm{C} 3$. The remaining $2 \mathrm{ml}$ were radiolabeled using $\mathrm{NaIO}_{4} / \mathrm{NaB}^{3} \mathrm{H}_{4}$ as described (13). The radiolabeled ghost proteins were then electrophoresed and fluorographs were prepared (13).

By titration experiments, it was determined that on a volume basis the purified anti-I was 10-fold more potent than CCAD serum at producing agglutination. Therefore, for experiments involving purified antibody, the IgM anti-I was diluted 1:10 in order to simulate CCAD serum conditions. To $1 \mathrm{ml}$ of packed normal $\mathrm{O}^{+}$erythrocytes washed in $\mathrm{GVB}^{++}, 300 \mu \mathrm{l}$ of purified cold agglutinin $(3.3 \mathrm{mg} / \mathrm{ml})$ diluted to 3 $\mathrm{ml}$ in $\mathrm{GVB}^{++}$was added. Controls for these experiments were erythrocytes incubated with $3 \mathrm{ml}$ of $\mathrm{GVB}^{++}$. The format for the remainder of the experiment was the same as that described above for normal erythrocytes plus CCAD serum.

For incubation of normal autologous serum or EDTA-serum with anti-I plus normal erythrocytes, cells were washed three times in either $\mathrm{GVB}^{++}$or GVB-EDTA. To $1 \mathrm{ml}$ of the erythrocytes washed in $\mathrm{GVB}^{++}$, 
$300 \mu \mathrm{l}$ of anti-I plus $2.7 \mathrm{ml}$ of autologous serum was added. To $1 \mathrm{ml}$ of packed erythrocytes washed in GVB-EDTA was added $300 \mu \mathrm{l}$ of anti-I plus $2.7 \mathrm{ml}$ of EDTA-chelated serum. The remainder of the format for the experiment was the same as that described above for normal erythrocytes plus CCAD serum.

Protein concentration. The protein concentration of the radiolabeled anti-C3dg, anti-CR1, anti-IgM, anti-C3c, and anti-IgG was determined using an $E_{1 \mathrm{~cm}}{ }^{1 \%}$ at $280 \mathrm{~nm}$ of 1.4 . Other protein determinations were made using Bio-Rad protein assay (Bio-Rad Laboratories) with bovine IgG as the standard.

Statistical methods. Group data were compared by Student's paired $t$ test.

\section{Results}

Patient profiles. CCAD is a disease of older patients (Table I) $(1,2)$. None of the patients included in this study had evidence of an associated neoplastic process. Patient R.H. was undergoing an accelerated hemolytic phase of his disease induced by events associated with surgery. As a result, he had been transferred to the Durham Veterans Administration Hospital, NC. He had been transfused with one unit of packed erythrocytes $12 \mathrm{~d}$ prior to initiation of the studies reported here. He had also been on chronic low-dose steroid therapy since the CCAD was originally diagnosed in 1969 . The steroids were tapered and discontinued while he was an outpatient. None of the other three patients had been transfused within the preceding year. Patients P.T. and A.B. were being treated with intermittent chlorambucil while patient C.P. was on no medications. All patients, except P.T., had associated acrocyanosis and/or coldrelated vaso-occlusive phenomena; patient C.P. was the most severely affected. The cold-reacting antibody in each case was defined as anti-I (as opposed to anti-i) since it reacted more strongly with adult erythrocytes than with fetal erythrocytes (Table I). As is almost invariably the case in CCAD with antiI specificity, the IgM cold agglutinins had kappa light chains (Table I), suggesting a monoclonal origin for the disease (2). The antibody titer was extremely variable among the four patients (Table I).

SDS-PAGE of radiolabeled CCAD erythrocytes. To determine if the erythrocytes of CCAD are abnormal, the terminal sialic acid residues of the membrane glycoproteins were oxidized with sodium meta-periodate, then labeled by reduction with tritiated sodium borohydride. The membrane proteins were then subjected to SDS-PAGE. There was no difference in the Coomassie staining pattern for CCAD erythrocytes compared with normal erythrocytes (Fig. 1). Fluorographs, however, revealed the presence of a band $\left(G_{\mathrm{ca}}\right)$ of $M_{\mathrm{r}}=126,000$ on the erythrocytes of the four patients with CCAD which was not present on normal erythrocytes (Fig. 1). This new band was completely trypsin-sensitive (data not shown) and was also visualized when the penultimate galactose residue of the cell-surface glycoproteins were radiolabeled [using neuraminidase, galactose oxidase, and tritiated sodium borohydride (13) (data not shown)]. The labeling pattern and susceptibility to trypsin suggested that $\mathrm{GP}_{\mathrm{ca}}$ might be composed, at least in part, of polymeric glycophorin- $\alpha$, the major erythrocyte sialoglycoprotein.

Immunological profile of $C C A D$ erythrocytes. In vivo activation of complement by the cold agglutinin antibody results in the fixation of $\mathrm{C} 3$ to the patient's erythrocytes. We have previously demonstrated that nascent $\mathrm{C} 3 \mathrm{~b}$ binds almost exclusively to the glycophorin- $\alpha$ dimer on human erythrocytes (13). It seemed possible then that the $\mathbf{G P}_{\mathrm{ca}}$ was a heteropolymer consisting of a fragment of $\mathrm{C} 3$ covalently bound to dimeric glycophorin- $\alpha$. Therefore, we assayed CCAD erythrocytes for the presence of erythrocyte-bound $\mathrm{C} 3$ fragments and immunoglobulins. No cell-associated IgM or IgG was detected (Table II). The anti-C3c recognizes an epitope expressed by $\mathrm{C} 3 \mathrm{~b}$ and iC $3 \mathrm{~b}$ while the anti-C3dg recognizes an epitope expressed by iC $3 \mathrm{~b}$ and C3dg. The antibody binding data demonstrate that the CCAD erythrocytes bear C3dg but not C3b or iC3b (Table II). This is consistent with the findings reported by Lachmann et al. (17).

Using the monoclonal antibody to $\mathrm{CR} 1$, we have observed that CRI sites are low on erythrocytes from patients with IgGmediated warm antibody hemolytic anemia who have C3dg present on their cells (18). We, therefore, used this antibody to determine CR1 sites on CCAD erythrocytes. The erythrocytes from all four patients had low numbers of $C R 1$ sites with the erythrocytes of three of the four patients having extremely low values (Table II).

Electrophoretic blotting of normal and CCAD erythrocyte membrane proteins with subsequent immune fixation with monoclonal anti-glycophorin and anti-C3dg. To determine if

Table I. Clinical and Laboratory Profile of Patients with CCAD

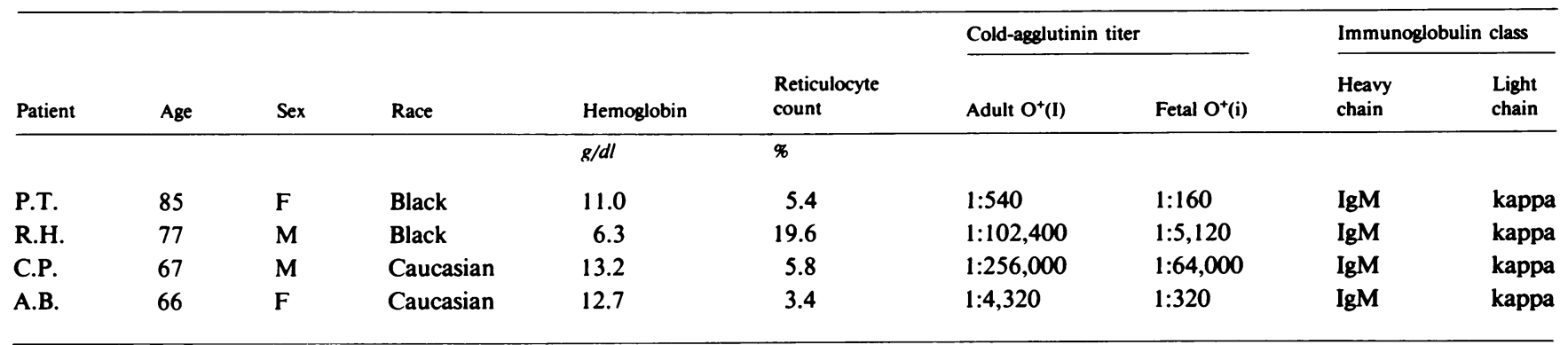



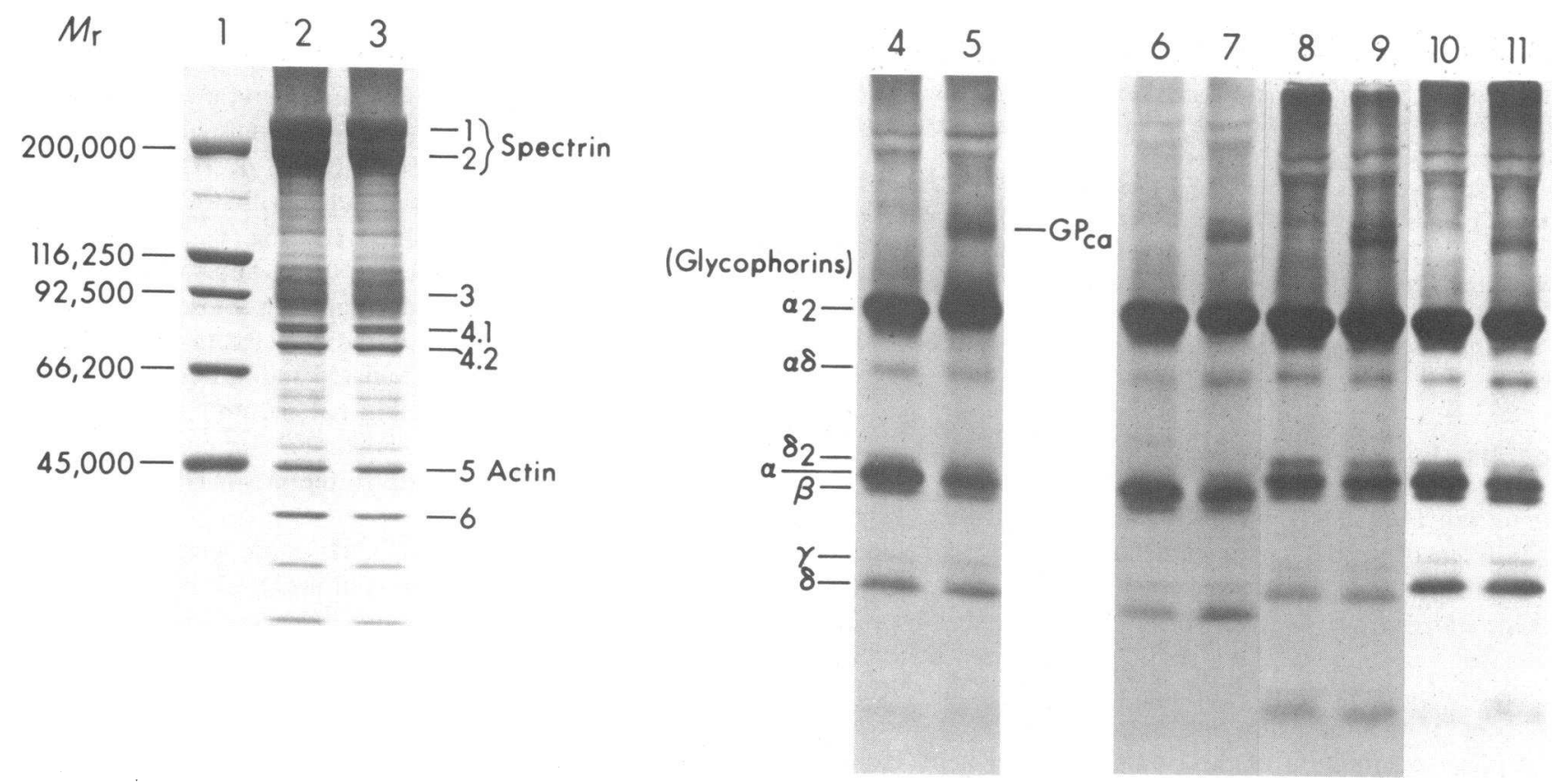

Figure 1. SDS-PAGE of normal and CCAD erythrocyte membrane proteins. The terminal sialic acid residues of membrane glycoproteins were radiolabeled using $\mathrm{NaIO}_{4} / \mathrm{NaB}^{3} \mathrm{H}_{4}$, then subjected to SDSPAGE. The gels were stained with Coomassie Blue and fluorographs were subsequently prepared. $25 \mu \mathrm{g}$ of erythrocyte membrane proteins were loaded onto each track. Lanes 1-3 are Coomassie-stained tracks. Lane 1, molecular weight markers; lane 2, erythrocyte membrane proteins from normal control; lane 3, erythrocyte membrane proteins from patient P.T. Lanes 4-11 are tracks from fluorographs. The

glycophorins are a composite part of $\mathrm{GP}_{\mathrm{ca}}$, normal and CCAD erythrocyte proteins were subjected to SDS-PAGE followed by immunoblotting and immunofixation using a monoclonal antibody which recognizes an epitope expressed by all species of glycophorin molecules including the homo and heterodimers (Fig. $2 A$, lane 1) (11). The antibody also interacts with normal erythrocytes membrane proteins at positions not heretofore associated with glycophorins (Fig. $2 \mathrm{~A}$, arrows 4 and 5). While direct proof is lacking, it seems likely that these proteins represent previously unrecognized homo or heteropolymers of glycophorin. For the CCAD erythrocytes, there is greater radioactivity at the position indicated by arrow 4 (Fig. $2 A$ lanes 2 and 4). In addition, there are three other radioactive bands of higher molecular weight present on the CCAD erythrocytes (Fig. $2 A$, arrows 1,2 , and 3 ). There is no obvious difference in the pattern of radioactivity for the erythrocytes membranes treated with hydroxylamine compared with their untreated counterparts (Fig. $2 A$, lane 1 compared with lane 3 , and lane 2 compared with lane 4). To determine if cellbound C3dg is involved in the formation of the complexes seen with CCAD erythrocytes in Fig. $2 A$, immunoblotting techniques (using the monoclonal antibody against C3dg for the immunofixation step) were again employed. There was no erythrocyte membrane protein source is as follows: lane 4, normal control; lane 5, patient P.T.; lane 6, normal control; lane 7, patient R.H.; lane 8, normal control; lane 9, patient C.P.; lane 10, normal control; lane 11, patient A.B. For the Coomassie-stained gels, there was no difference in the staining pattern between normal and CCAD erythrocyte membrane proteins. The fluorographs show the appearance of an abnormal glycoprotein associated with the CCAD erythrocytes $\left(\mathrm{GP}_{\mathrm{ca}}\right)$. The Greek symbols denote the glycophorin monomers and homo- and heterodimers.

Table II. Immunological Profile of CCAD Erythrocytes

\begin{tabular}{lllllc}
\hline Patient & IgM* & IgG $¥$ & C3c§ & $\begin{array}{l}\text { C3dg" } \\
\text { (Molecules/cell) }\end{array}$ & $\begin{array}{l}\text { CR1\% } \\
\text { (Sites/cell) }\end{array}$ \\
\hline P.T. & Neg. & Neg. & Neg. & 11,415 & 44 \\
R.H. & Neg. & Neg. & Neg. & 1,371 & 78 \\
C.P. & Neg. & Neg. & Neg. & 9,107 & 263 \\
A.B. & Neg. & Neg. & Neg. & 4,783 & 72 \\
\hline
\end{tabular}

Neg., negative.

* Cell-bound IgM was determined using a ${ }^{125}$ I-labeled affinity-purified goat antihuman IgM. Negative means that there was no statistically significant difference $(n=5)$ in the binding of the ${ }^{125}$ I-anti-IgM to the erythrocytes in the presence and absence of a $50 \mathrm{M}$ excess of unlabeled antibody.

¥ Cell-bound IgG was determined using ${ }^{125} \mathrm{I}$-monoclonal anti-IgG. Negative means there was no statistically significant difference $(n=5)$ between the amount of ${ }^{125}$ I-anti-IgG bound to patients' cells as compared with normal erythrocytes.

§ Cell-bound $\mathrm{C} 3 \mathrm{c}$ was determined using ${ }^{125} \mathrm{I}$-monoclonal anti-C $3 \mathrm{c}$. Negative means there was no statistically significant difference $(n=5)$ between the amount of ${ }^{125} \mathrm{I}$-anti-C $3 \mathrm{c}$ bound to patients' cells as compared with normal erythrocytes.

"Cell-bound C3dg ws determined using ${ }^{125} \mathrm{I}$-monoclonal anti-C3dg. The value represents the mean of triplicate determination.

IT The number of CR1 sites was determined using monoclonal ${ }^{125}$ I-anti-CR I. The value represents the mean of triplicate experiments. The range for normals is $481-1098$ sites/cell, and the mean \pm 1 SD is $710 \pm 180(n=16)$. 


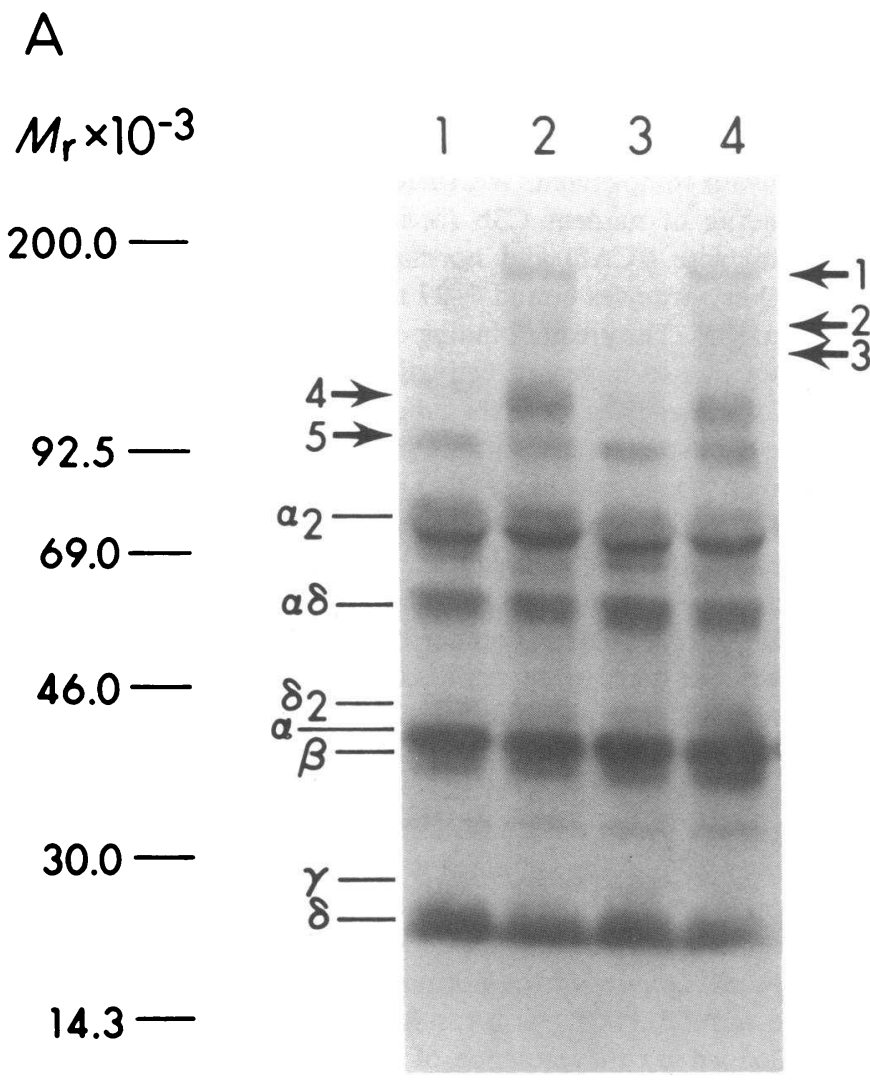

Figure 2. Autoradiograph of immunoblots of erythrocyte membrane proteins. Ghosts prepared from the erythrocytes of a normal control and of a patient with CCAD (P.T.) were solubilized in SDS. Part of the solubilized ghosts from each set were treated with hydroxylamine to release ester bound C3dg. $50 \mu \mathrm{g}$ of membrane proteins were subjected to SDS-PAGE under reducing conditions, then electrophoretically transferred to nitrocellulose paper. The nitrocellulose paper was incubated with either mouse monoclonal anti-glycophorin $(A)$ or rat monoclonal anti-C3dg $(B)$. The paper was washed, and then incubated with either affinity-purified sheep ${ }^{125} \mathrm{I}-\left(\mathrm{Fab}^{\prime}\right)_{2}$ anti-mouse IgG $(A)$ or anti-rat $\operatorname{IgG}(B)$. After washing, the paper was dried and autoradiographs were prepared. $(A)$ Immunoblots developed with monoclonal anti-glycophorin. Lane 1, erythrocyte membrane proteins from a normal control; lane 2, erythrocyte membrane proteins from a patient with CCAD (P.T.); lane 3, erythrocyte membrane proteins from the normal controls treated with $\mathrm{NH}_{2} \mathrm{OH}$; lane 4, erythrocyte membrane proteins from the patient (P.T.) with CCAD treated with $\mathrm{NH}_{2} \mathrm{OH}$. Arrows 1-3 denote high molecular weight bands associated with both the hydroxylamine-treated and untreated CCAD erythro-

interaction of the antibody with normal erythrocytes (Fig. 2 $B$, lanes 1 and 3 ). For the CCAD erythrocytes, radioactive bands were seen in positions corresponding to arrows 1-4 in Fig. $2 A$ (Fig. $2 B$, lane 2). When the CCAD erythrocytes were treated with hydroxylamine, a prominent band of molecular weight $36.5 \mathrm{kD}$ appeared (Fig. $2 \mathrm{~B}$, lane 4).

The data represented in Fig. 2, $A$ and $B$ suggest that $\mathrm{GP}_{c a}$ is composed, at least in part, of glycophorin and C3dg,

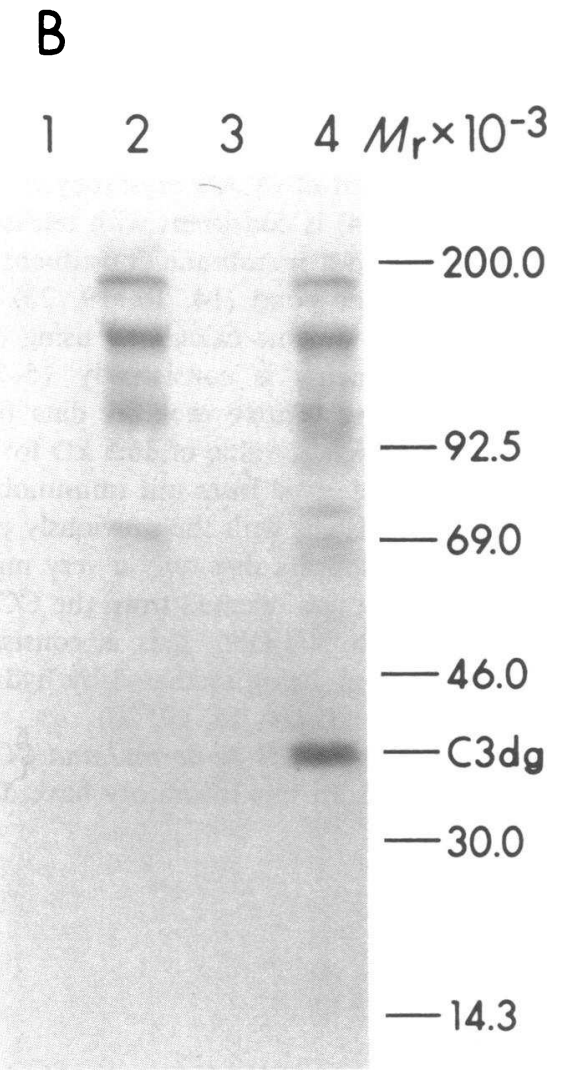

cyte membrane proteins but not with their normal counterparts. Arrows 4 and 5 denote bands at positions not ordinarily associated with glycophorin molecules. These bands are seen for both hydroxylamine-treated and untreated normal and CCAD erythrocyte membrane proteins, but there is greater radioactivity in the area denoted by arrow 4 for the CCAD erythrocytes. The Greek symbols denote the positions of the glycophorin monomers and homo- and heterodimers. $(B)$ Immunoblot developed with monoclonal anti-C3dg. Lane 1 , erythrocyte membrane proteins from the normal control; lane 2, erythrocyte membrane proteins from the patient (P.T.) with CCAD; lane 3, erythrocyte membrane proteins from the normal control treated with hydroxylamine; lane 4 , erythrocyte membrane proteins from the patient (P.T.) with CCAD treated with hydroxylamine. The most intensely staining bands in lanes 2 and 4 correspond in position to the bands denoted by arrows $1-4$ in $(A)$ suggesting that they represent complexes of $\mathrm{C} 3 \mathrm{dg}$ covalently bound to glycophorin molecules. Treatment of the CCAD membrane proteins with $\mathrm{NH}_{2} \mathrm{OH}$ (lane 4) releases ester-bound C3dg, allowing it to run in its normal uncomplexed position.

although the stoichiometric relationship between the two proteins and the exact subunit composition of the complexes cannot be determined from these experiments. GlycophorinC3dg complexes of higher molecular weight are also observed for the CCAD erythrocytes. Indeed, the most intensely radioactive bands seen in the immunoblot developed with the antiC3dg (Fig. 2 B) are these higher molecular weight complexes (Fig. $2 B$, arrows 1 and 2). Whether this greater radioactivity 
is due to a higher ratio of $\mathrm{C} 3 \mathrm{dg}$ to glycophorin molecules or to conformational differences of the $\mathrm{C} 3 \mathrm{dg}$ molecules within these complexes which makes the $\mathrm{C} 3 \mathrm{dg}$ more accessible to interaction with the antibody is uncertain. The appearance of the $36.5 \mathrm{kD}$ band after treatment of CCAD erythrocytes with hydroxylamine (Fig. $2 \mathrm{~B}$, lane 4 ) is consistent with release of C3dg which had been bound to a membrane constituent via an hydroxylamine-sensitive ester bond $(14,15,19,20)$. (In our experience, the molecular weights calculated using data from immunoblotting experiments is consistently 15-20\% lower than that calculated using relative mobility data from SDS-PAGE systems alone. Thus, the value of $36.5 \mathrm{kD}$ for the molecular weight of the $\mathrm{C} 3 \mathrm{dg}$, derived from our immunoblotting experiments, is not inconsistent with the previously published value of $41 \mathrm{kD}$ [7]). It appears that only a very minor fraction of the cell-bound C3dg was released from the CCAD erythrocytes by treatment with $\mathrm{NH}_{2} \mathrm{OH}$. This is consistent with the majority of the bonding being mediated by hydroxylamine-resistant imidoester bonds $(14,15,19,20)$.

Efficiency of binding of nascent $C 3 b$ to normal and $C C A D$ erythrocytes. Previous studies from this laboratory have dem-

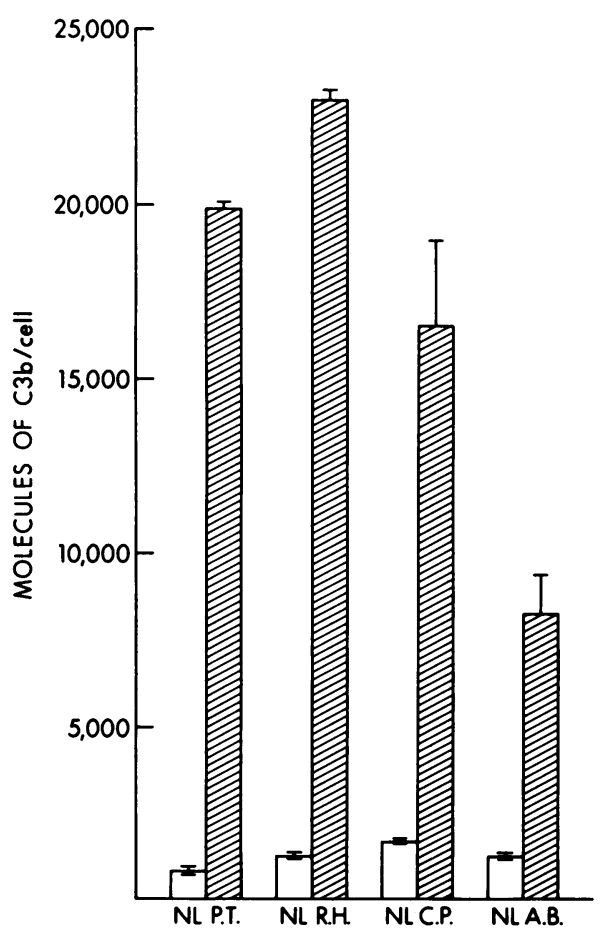

Figure 3. Greater binding of fluid-phase activated C3b to chronic cold agglutinin disease erythrocytes. Purified $\mathrm{C} 3$ was activated in the fluid-phase using activated $\mathrm{CoFBb}$ in the presence of normal and CCAD erythrocytes. The cells were then washed and the amount of $\mathrm{C} 3 \mathrm{~b}$ bound was determined using ${ }^{125} \mathrm{I}$-anti-C3c. The initials are those of the individual patients with CCAD and NL denotes the normal control. The value depicted by the bar represents the mean $\pm 1 \mathrm{SD}, n$ $=3$. The CCAD erythrocytes bind 7-27 times more C $3 \mathrm{~b}$ than normal control erythrocytes. onstrated that abnormalities in glycophorin influence the functional activity of complement (13). Because $\mathrm{GP}_{\mathrm{ca}}$ is composed, at least in part, of glycophorin, it seemed possible that its presence on CCAD erythrocytes might induce aberrent interaction with complement. We, therefore, compared the efficiency of binding of nascent $\mathrm{C} 3 \mathrm{~b}$ (activated in the fluid-phase by $\mathrm{CoFBb}$ ) with CCAD and normal erythrocytes (Fig. 3). The CCAD erythrocytes bound 7-27 times more C3b than normal erythrocytes. The greater binding of $\mathrm{C} 3 \mathrm{~b}$ to CCAD erythrocytes was not due to increased activation of $\mathrm{C} 3$ in the presence of CCAD erythrocytes since the amount of $\mathrm{C} 3$ converted to $\mathrm{C} 3 \mathrm{~b}$ by the $\mathrm{CoFBb}$ complexes in the presence of each cell type was essentially the same (Table III).

$S D S-P A G E$ and autoradiography of normal and CCAD erythrocytes bearing radiolabeled $C 3 b\left(E C 3 b^{*}\right)$. To determine if there existed a difference in the pattern of binding of $\mathrm{C} 3 \mathrm{~b}$ to CCAD erythrocytes compared with normal erythrocytes, the two cell-types were exposed to radiolabeled $\mathrm{C} 3$ in the presence $\left(\mathrm{EC} 3 \mathrm{~b}^{*}\right)$ and absence $\left(\mathrm{EC} 3^{*}\right)$ of $\mathrm{CoFBb}$ complexes (Fig. 4). The specific activity of the CCAD EC $3 b^{*}$ membrane proteins was 25 times greater than that of their normal counterpart, which was consistent with the markedly increased efficiency of binding of nascent C3b to CCAD erythrocytes previously demonstrated. Because of the low efficiency of binding of fluid-phase activated C $3 \mathrm{~b}$ to normal erythrocytes, the specific activity of the normal EC3b* was only twice that of the normal EC3*. As a result, nonspecifically bound ${ }^{125} \mathrm{I}-$ C3 (defined by the presence of the $\mathrm{C} 3 \alpha$-chain) is visible in tracks 1 and 2 of Fig. 4. In contrast, the specific activity of the CCAD EC3* was $<4 \%$ of that of the CCAD EC3b*.

The pattern of binding of ${ }^{125} \mathrm{I}-\mathrm{C} 3 \mathrm{~b}$ to CCAD erythrocytes is clearly different than that of binding to normal EC $3 b^{*}$ (Fig. 4 , lane 4 vs. lane 2). For normal EC3b*, the majority of the bound ${ }^{125} \mathrm{I}-\mathrm{C} 3 \mathrm{~b}$ is part of a complex of $M_{\mathrm{r}}=255,000$ (Fig. 4, lane 2) (this pattern of binding of fluid-phase activated ${ }^{125} I-$

Table III. Conversion of C3 by Activated CoF Complexes in the Presence of Normal and CCAD Erythrocytes

\begin{tabular}{lc}
\hline Erythrocyte source & Percent C3 converted to C3b* \\
\hline P.T. & 100 \\
Normal control & 97 \\
R.H. & 94 \\
Normal control & 91 \\
C.P. & 100 \\
Normal control & 88 \\
A.B. & 95 \\
Normal control & 91
\end{tabular}

\footnotetext{
* Determined by crossed immunoelectrophoresis. The value represents the mean percent conversion of $\mathrm{C} 3$ to $\mathrm{C} 3 \mathrm{~b}$ in the three activation experiments. The amount of $\mathrm{C} 3 \mathrm{~b}$ subsequently bound to the erythrocytes is shown in Fig. 3.
} 


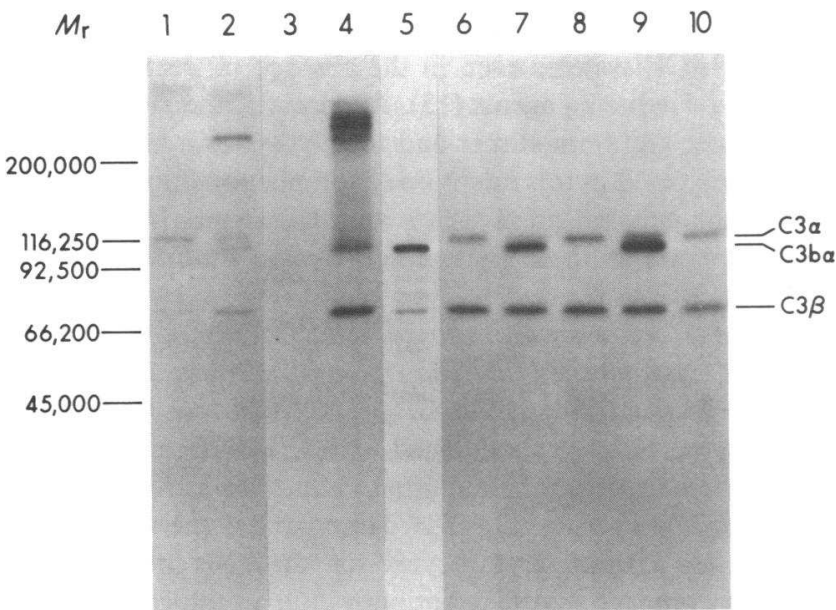

Figure 4. Autoradiograph of normal and CCAD erythrocytes bearing radiolabeled C3b. Normal and CCAD erythrocytes were exposed to ${ }^{125} \mathrm{I}-\mathrm{C} 3$ in the presence $\left(\mathrm{EC} 3 \mathrm{~b}^{*}\right)$ or absence $\left(\mathrm{EC} 3^{*}\right)$ of $\mathrm{CoFBb}$, the supernates were aspirated and ghost were prepared from the erythrocytes. After solubilizing in SDS, the membrane proteins and the supernates were subjected to SDS-PAGE under reducing conditions. A portion of the solubilized membrane proteins from the CCAD $\mathrm{EC} 3 \mathrm{~b}^{*}$ were treated with hydroxylamine to release ester-bound $\mathrm{C} 3 \mathrm{~b}$ prior to electrophoresis. Lane 1, normal EC3*; lane 2, normal EC3b*; lane 3, CCAD EC3*; lane 4, CCAD EC3b*; lane 5, CCAD $\mathrm{EC}^{*} \mathrm{~b}^{*}$ treated with $\mathrm{NH}_{2} \mathrm{OH}$; lane 6, supernate from normal EC3*; lane 7, supernate from normal EC $3 b^{*}$; lane 8, supernate from CCAD EC3*; lane 9, supernate from CCAD EC3b*; lane $10,{ }^{125} \mathrm{I}-\mathrm{C} 3$ not exposed to cells or $\mathrm{CoFBb}$ complexes. The pattern of binding of $\mathrm{C} 3 \mathrm{~b}$ to the CCAD erythrocytes is markedly different than to normal cells (lane 4 vs. lane 2). Hydroxylamine releases the $\mathrm{C} 3 \mathrm{~b} \alpha$-chain from its complexed position, suggesting that the $\alpha$-chain was bound to membrane constituents via an ester bond.

C3b to normal erythrocytes is the same as that seen when ${ }^{125} \mathrm{I}$ $\mathrm{C} 3 \mathrm{~b}$ is activated by the cell-bound nephritic factor-stabilized alternative pathway convertase [13]). In addition to the 255 $\mathrm{kD}$ band seen with the normal EC $3 \mathrm{~b}^{*}$, the CCAD EC $3 \mathrm{~b}^{*}$ have two higher molecular weight ${ }^{125} \mathrm{I}-\mathrm{C} 3 \mathrm{~b} \alpha-\mathrm{E}$ complexes (Fig. 4, lane 4). When the CCAD EC3b* were treated with hydroxylamine, all of the ${ }^{125} \mathrm{I}-\mathrm{C} 3 \mathrm{~b} \alpha$-chain was released from the higher molecular weight complexes, suggesting that the $\alpha$-chain had been covalently bound to CCAD erythrocytes membrane constituents via an ester bond (Fig. 4, lane 5). This contrasts sharply with results of the experiment depicted in Fig. $2 B$ in which only a very small portion of the cell-bound C3dg was susceptible to release by treatment with hydroxylamine (Fig. 2 $B$, lane 4).

There was no activation of $\mathrm{C} 3$ in the absence of CoFBb complexes (Fig. 4, lanes 6 and 8) and the amount of $C 3$ activated by the CoFBb complexes in the presence of normal erythrocytes was the same as that in the presence of CCAD erythrocytes [defined by ratio of ${ }^{125} \mathrm{I}-\mathrm{C} 3:{ }^{125} \mathrm{I}-\mathrm{C} 3 \mathrm{~b}$ (Fig. 4, lane 7 compared with lane 9)].
Binding of $C 3 b$ to radiolabeled $C C A D$ erythrocytes. CCAD erythrocytes were first radiolabeled with ${ }^{125} I$ and then exposed to unlabeled $C 3$ in the presence $\left(E^{*} C 3 b\right)$ or absence $\left(E^{*} C 3\right)$ of $\mathrm{CoFBb}$ complexes. Autoradiographs of the radiolabeled membrane proteins after SDS-PAGE demonstrated the appearance of two high molecular weight bands for the CCAD $E^{*} \mathrm{C} 3 \mathrm{~b}$ (Fig. 5, lane 1). These bands correspond in electrophoretic mobility to the two higher molecular weight bands seen for the CCAD EC3b* (Fig. 4, lane 4). Unlabeled CCAD erythrocytes were also exposed to unlabeled $\mathrm{C} 3$ in the presence $\left(E_{\mathrm{p}}^{*} \mathrm{C} 3 \mathrm{~b}^{*}\right)$ or absence $\left(\mathrm{E}_{\mathrm{p}}^{*} \mathrm{C} 3^{*}\right)$ of $\mathrm{CoFBb}$ complexes then radiolabeled using periodate and titrated borohydride. In this experiment, then, there is potential for simultaneous labeling of both the membrane glycoproteins and cell-bound C $3 \mathrm{~b}$. The higher molecular weight bands seen with the $\mathrm{E}^{*} \mathrm{C} 3 \mathrm{~b}$ (Fig. 5 , lane 1) are also seen with the $\mathrm{E}_{\mathrm{p}}^{*} \mathrm{C} 3 \mathrm{~b}^{*}$ (Fig. 5, lane 4). In addition, the $255 \mathrm{kD}$ band seen with the CCAD EC3b* (Fig. 4 , lane 4 ) is also faintly visible. This experiment also shows radiolabeling of the $\beta$-chain of $C 3$ (Fig. 5, lanes 3 and 4) demonstrating that the carbohydrate moiety of this chain has sialic acid constituents, and that these residues are accessible to oxidation by periodate.

Both radiolabeling techniques label $\mathrm{GP}_{\mathrm{ca}}$, although the intensity of labeling is relatively poor in the ${ }^{125} \mathrm{I}$ system (Fig. 5), suggesting that the conformation of the $\mathrm{GP}_{\mathrm{ca}}$ is such that its tyrosine residues are not readily available for incorporation of the ${ }^{125} \mathrm{I}$. For both the CCAD $E^{*} \mathrm{C} 3 \mathrm{~b}$ and the $\mathrm{E}_{\mathrm{p}}^{*} \mathrm{C} 3 \mathrm{~b}^{*}$, there appears to be less radioactivity of $\mathrm{GP}_{\mathrm{ca}}$ than for their control counterparts $\left(E^{*} \mathrm{C} 3\right.$ and $E_{p}^{*} C 3^{*}$, respectively) (Fig. 5, lane 1 vs. lane 2 , and lane 4 vs. lane 3 ), suggesting that $C 3 b$ is binding to $\mathrm{GP}_{\mathrm{ca}}$ and thereby displacing it from its normal position.

Two dimensional gel electrophoresis of $C C A D E^{*} C 3 b$. It seemed likely that the difference in the efficiency and pattern of binding of fluid-phase activated C3b to CCAD erythrocytes related to the presence of the $\mathrm{GP}_{\mathrm{ca}}$ on these cells. To determine

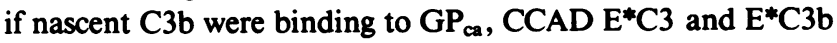
were subjected to SDS-PAGE in the first dimension. The tracks were then isolated and treated with $\mathrm{NH}_{2} \mathrm{OH}$. Following electrophoresis in the second dimension, autoradiographs were prepared.

After release of the $\mathrm{C} 3 \mathrm{~b} \alpha$ chain by $\mathrm{NH}_{2} \mathrm{OH}$, the membrane component of the $\mathrm{E}^{*}-\mathrm{C} 3 \mathrm{~b} \alpha-$-complex was seen to migrate in the same horizontal planes as the glycophorin- $\alpha$ monomer and dimer (Fig. $6 \mathrm{~A}$, arrows 1 and 2). Corresponding areas of exposure were not seen on the film of the $\mathrm{NH}_{2} \mathrm{OH}$-treated $\mathrm{E}^{*} \mathrm{C} 3$ (Fig. $6 \mathrm{~B}$ ). However, one cannot conclude from these experiments that nascent $\mathrm{C} 3 \mathrm{~b}$ is not binding to $\mathrm{GP}_{\mathrm{ca}}$, since $\mathrm{GP}_{\mathrm{ca}}$ itself consists predominately of glycophorin- $\alpha$ (Fig. $6 \mathrm{~A}$ and $B$, arrows 3 and 4). The immunoblotting experiments described above suggested that $\mathrm{C} 3 \mathrm{dg}$ is also a composite part of the $\mathrm{GP}_{\mathrm{ca}}$. However, no constituents of $\mathrm{GP}_{\mathrm{ca}}$ other than the glycophorin- $\alpha$ monomer and dimer are visualized in the autoradiographs of the two-dimensional gels. This suggests that either the ratio of $\mathrm{C} 3 \mathrm{dg}$ to glycophorin- $\alpha$ in the $\mathrm{GP}_{\mathrm{ca}}$ is so low 


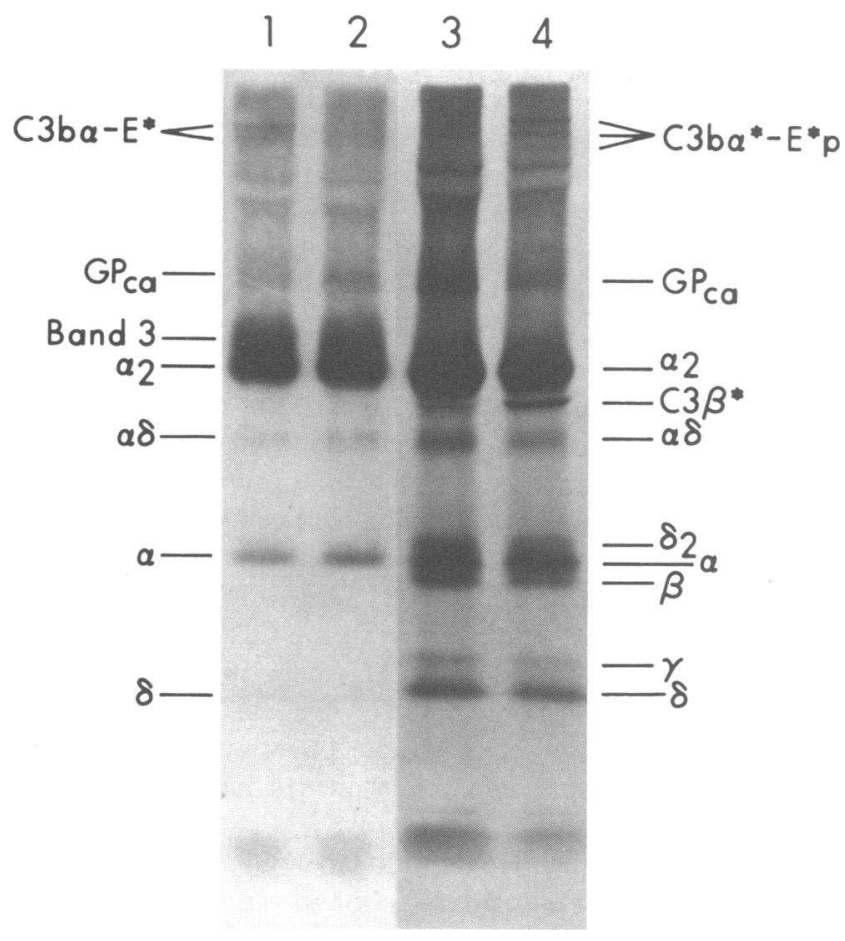

Figure 5. Radiolabeled CCAD erythrocytes bearing C3b. CCAD erythrocytes were radiolabeled with ${ }^{125}$ I using the IODO-GEN method then exposed to unlabeled $\mathrm{C} 3$ in the presence $\left(\mathrm{E}^{*} \mathrm{C} 3 \mathrm{~b}\right)$ or absence $\left(\mathrm{E}^{*} \mathrm{C} 3\right)$ of activated $\mathrm{CoF}$ complexes. Ghosts were prepared, solubilized in SDS, and electrophoresed under reducing conditions. After staining and destaining, autoradiographs were prepared: lane 1, CCAD E*C3b; lane 2, CCAD E*C3. C3b $\alpha-E^{*}$ denotes a complex of $\mathrm{C} 3 \mathrm{~b} \alpha$-chain covalently bound to a radiolabeled membrane constituent. $\mathrm{GP}_{\mathrm{ca}}$ is the abnormal membrane glycoprotein associated with CCAD. Band 3 is a normal integral membrane glycoprotein which is radiolabeled when this iodination procedure is employed. The Greek symbols denote the glycophorin monomers and homo- and heterodimers. Lanes 3 and 4 are tracks from the fluorograph of CCAD erythrocytes which were exposed to unlabeled $C 3$ in the presence $\left(\mathrm{E}^{*} \mathrm{p} 3 \mathrm{~b}^{*}\right)$ and absence $\left(\mathrm{Ep}^{*} \mathrm{C} 3^{*}\right)$ of $\mathrm{CoFBb}$, then radiolabeled using periodate and tritiated borohydride. After solubilization in SDS, the membrane proteins were subjected to SDS-PAGE. The gels were stained and destained, and fluorographs were prepared: lane 3, CCAD E*pC3*; lane 4, CCAD E* pC $3 b^{*}$. C3b* $\alpha-E^{*} p$ denotes a complex of $\mathrm{C} 3 \mathrm{~b} \alpha$-chain covalently bound to an erythrocyte membrane constituent. Because the cells were labeled after binding of $\mathrm{C} 3 \mathrm{~b}$ to the membrane surface, there is potential for radiolabeling both the $\mathrm{C} 3 \mathrm{~b} \alpha$-chain component and the erythrocyte membrane component of the complex. $\mathbf{G P}_{\mathrm{ca}}$ is the abnormal membrane protein associated with CCAD erythrocytes. The Greek symbols denote the glycophorin monomers and homodimers and heterodimers. $\mathrm{C}_{3} \mathrm{~B}^{*}$ denotes the position of the uncomplexed $\beta$-chain of $\mathrm{C} 3 \mathrm{~b}$ which is radiolabeled.

that the labeled complexes containing $\mathrm{C} 3 \mathrm{dg}$ are not seen under these conditions of exposure, or that the presence of the $\mathrm{C} 3 \mathrm{dg}$ within the complex is such that it induces conformational changes which inhibit radiolabeling of the constituents.
The glycophorin- $\alpha$ monomer and homodimer interconvert in SDS-PAGE systems even in the absence of treatment with $\mathrm{NH}_{2} \mathrm{OH}$ or reducing agents (13). Apparently, the glycophorin$\delta$ monomer and homodimer and the glycophorin-heterodimer are also involved in this interconversion phenomenon accounting for the exposed areas which are off-diagonal in the same vertical planes as these glycoproteins when on-diagonal (Fig. 6, $A$ and $B$ ).

Normal erythrocytes exposed to CCAD serum, purified antibody, and purified antibody plus autologous serum and plasma. To determine if the $\mathrm{GP}_{\mathrm{ca}}$ were inducible on normal erythrocytes, cells were incubated with CCAD serum, purified antibody alone, or purified antibody plus autologous serum or EDTA-chelated serum. Fig. $7 A$ demonstrates the appearance of $\mathrm{GP}_{\mathrm{ca}}$ on normal erythrocytes for the cells treated with CCAD serum and purified antibody plus autologous serum, but not with purified antibody alone or purified antibody plus autologous plasma. Increased efficiency of binding of fluid-phase activated $\mathrm{C} 3 \mathrm{~b}$ was likewise seen with the cells which manifested the $G_{c a}$ but not with those which did not (Fig. 7 B).

Normal erythrocytes which had been incubated with CCAD serum were also assayed for the presence of cell-bound IgM, IgG, C3c, and C3dg, and for CR1 sites (Table IV). Essentially all cell-bound $\mathrm{C} 3 \mathrm{~b}$ was converted to $\mathrm{C} 3 \mathrm{dg}$ during the incubation period, but neither this conversion process nor the presence of large amounts of $\mathrm{C} 3 \mathrm{dg}$ effected a reduction in the number of CR1 sites (Table IV).

These experiments demonstrate that the interactions of the cold agglutinin and complement with erythrocyte membrane glycoproteins produce the $\mathrm{GP}_{\mathrm{ca}}$ and the associated greater efficiency of binding of nascent $\mathrm{C} 3 \mathrm{~b}$.

\section{Discussion}

The studies reported here demonstrate that in vivo and in vitro interactions of IgM cold-reacting antibodies and complement with the erythrocyte membrane induce changes in cellsurface glycoproteins, and that these alterations modify subsequent interaction with complement.

The abnormal membrane protein associated with CCAD $\left(G_{\mathrm{ca}}\right)$ appears to consist primarily of glycophorin- $\alpha$ and $\mathrm{C} 3 \mathrm{dg}$ (Fig. 2, $A$ and $B$ ). Because antigenic determinants of the I system are present on glycophorin molecules $(1,2)$, it would appear that $\mathrm{GP}_{\mathrm{ca}}$ formation is the result of activation of complement by anti-I with subsequent binding of $\mathrm{C} 3 \mathrm{~b}$ (which is ultimately degraded to C3dg [6]) to glycophorin- $\alpha$. However, the results of the two-dimensional gel experiments (Fig. 6, $A$ and $B$ ) which show dissociation of $\mathrm{GP}_{\mathrm{ca}}$ into subunits of glycophorin- $\alpha$ dimer and monomer without evidence of $\mathrm{C} 3 \mathrm{dg}$ either complexed or uncomplexed, suggest that $\mathbf{G P}_{\mathrm{ca}}$ does not consist of glycophorin- $\alpha$ (or glycophorin- $\alpha$ dimer) and C3dg in a 1:1 stoichiometric relationship. Rather, we postulate that $\mathrm{GP}_{\mathrm{ca}}$ consists predominately of trimeric glycophorin- $\alpha$, with the interactions of the cold-reacting antibody and complement 

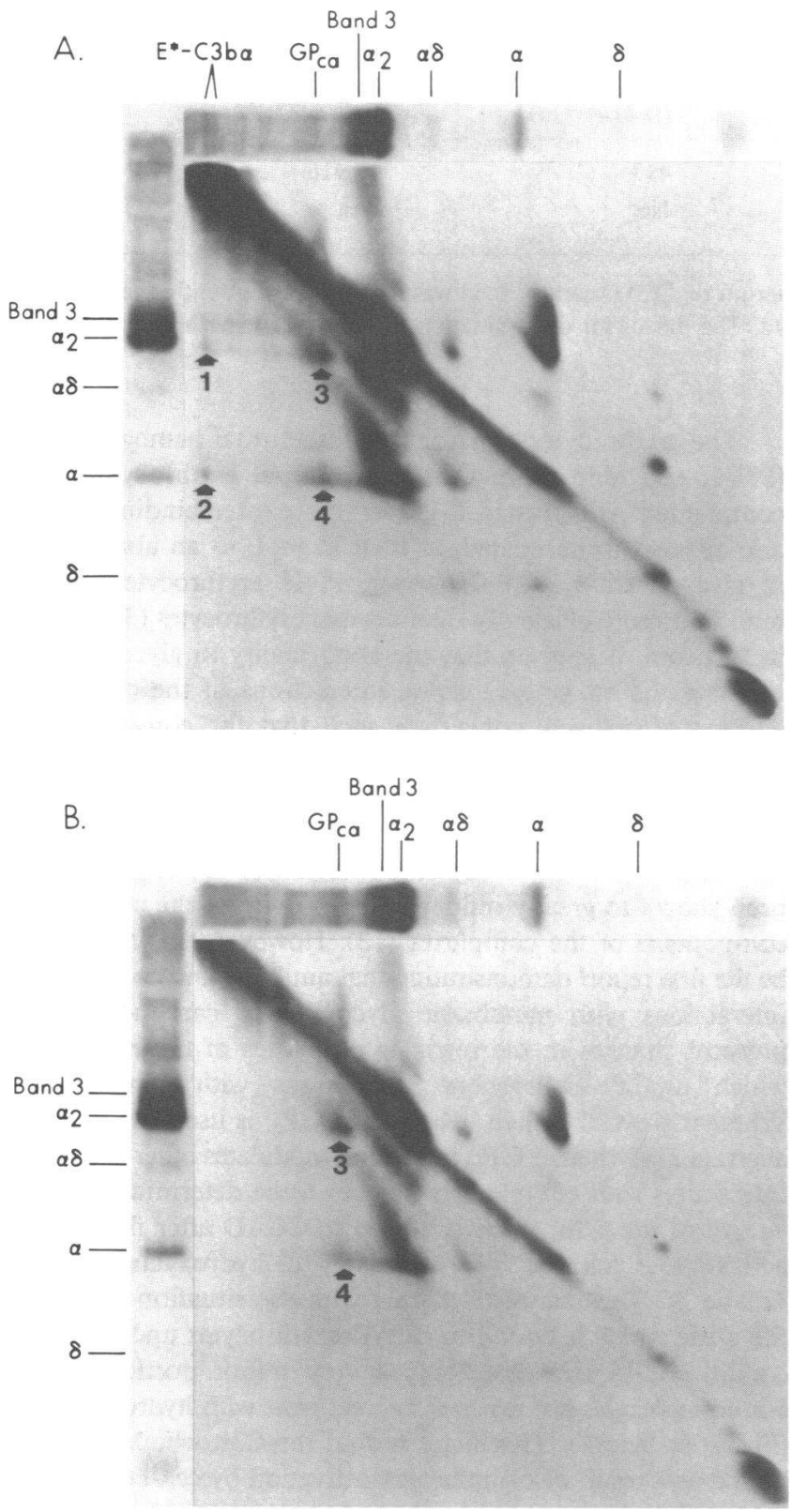

Figure 6. Autoradiograph of two-dimensional gel analysis of the CCAD $\mathrm{E}^{*} \mathrm{C} 3 \mathrm{~b}(A)$ and $\mathrm{E}^{*} \mathrm{C} 3(B)$ membrane proteins described under Fig. 4, lanes 1 and 2. After electrophoresis of the proteins in the first dimension, the tracks were isolated, treated with hydroxylamine to release the ester bound $\mathrm{C} 3 \mathrm{~b}$, and electrophoresed in the second dimension under reducing conditions. $(A) \mathrm{E}^{*} \mathrm{C} 3 \mathrm{~b}$. An autoradiograph of the track after electrophoresis in the first dimension is placed above and beside the film to define the vertical and horizontal planes of the radiolabeled membrane proteins. Arrows 1 and 2 denote the radiolabeled membrane constituents of the $\mathrm{E}^{*} \mathrm{C} 3 \mathrm{~b}$ complex, which are released by treatment with $\mathrm{NH}_{2} \mathrm{OH}$, subsequently electrophorese in the same horizontal planes as the glycophorin- $\alpha$ dimer and monomer. Arrows 3 and 4 denote that the exposed areas which are off-
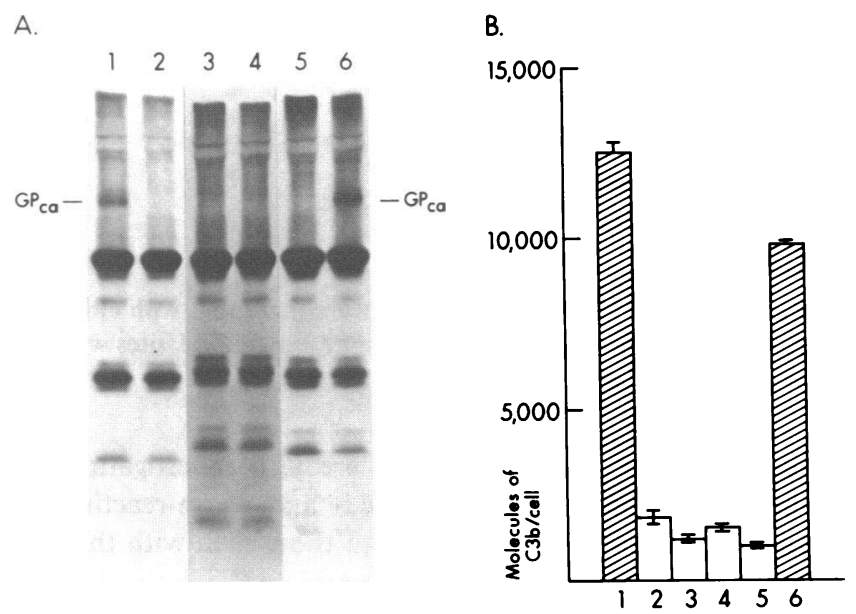

Figure 7. Normal erythrocytes treated with anti-I and complement. $(A)$ Normal erythrocytes were incubated with serum from patient with CCAD (P.T.) (lane 1), serum from a normal donor (lane 2), purified cold agglutinin alone (from patient P.T.) (lane 3), buffer alone (lane 4), purified cold agglutinin antibody plus autologous EDTA-chelated serum (lane 5), or purified cold agglutinin antibody plus autologous serum (lane 6). The cells were then washed, radiolabeled using $\mathrm{NaIO}_{4} / \mathrm{NaB}^{3} \mathrm{H}_{4}$, and the solubilized ghosted proteins were subjected to SDS-PAGE. After staining and destaining, fluorographs were prepared. The abnormal glycoprotein associated with CCAD $\left(G_{c a}\right)$ appeared on the cells treated with CCAD serum, and on those treated with purified antibody plus autologous serum. (B) After treating the normal erythrocytes as described in the $(A)$ portion of this illustration, the cells were washed, and purified $C 3$ was activated in the fluid-phase using activated $\mathrm{CoFBb}$ in the presence of each cell type. The cells were washed again and the amount of $\mathrm{C} 3 \mathrm{~b}$ bound was determined using ${ }^{125}$ I-anti-C3c. The numbering system for the bars is the same as for the tracks of the fluorograph shown in $A$, and the value depicted represents the mean $\pm 1 \mathrm{SD}, n=3$. The cells which

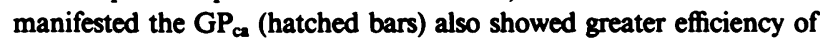
binding of $\mathrm{C} 3 \mathrm{~b}$.

(possibly including components of the cascade beyond C3) with glycophorin- $\alpha$ being responsible for the biophysical changes which effect the formation of the polymer. Studies using sera deficient in particular complement components are underway to determine which elements of the complement system are

diagonal in the same vertical plane as $\mathbf{G P}_{\mathrm{a}}$ are also in the same horizontal plane as the glycophorin- $\alpha$ dimer and monomer. This latter phenomenon occurs even in the absence of hydroxylamine treatment and of reducing agents. The glycophorin monomers and homo- and heterodimers interconvert in SDS-PAGE systems, accounting for the appearance of the exposed areas which are offdiagonal in the same vertical planes as these glycophorin species when on-diagonal. (B) EC3*. This autoradiograph is identical to that described under Fig. $5 \mathrm{~A}$ except that the exposed areas denoted by arrows 1 and 2 in Fig. $5 A$ do not appear since these radiolabeled erythrocytes bore no covalently bound $\mathrm{C} 3 \mathrm{~b}$. 
Table IV. Immunological Profile of Normal Erythrocytes Exposed to CCAD Serum*

\begin{tabular}{llllll}
\hline & IgM & IgG & $\begin{array}{l}\text { C3c } \\
\text { (Molecules/cell) }\end{array}$ & $\begin{array}{l}\text { C3dg } \\
\text { (Molecules/cell) }\end{array}$ & $\begin{array}{l}\text { CR1 } \\
\text { (Sites/cell) }\end{array}$ \\
\hline $\begin{array}{l}\text { Normal erythrocytes + CCAD serum } \\
\text { Normal erythrocytes + Control serum }\end{array}$ & Neg. & Neg. & 413 & 17,916 & 691 \\
& Neg. & Neg. & Neg. & Neg. & 683 \\
\hline
\end{tabular}

Neg., negative. * Normal erythrocytes were incubated with either control serum or CCAD serum, then washed and the amount of cell-bound IgM, IgG, C3c, and C3dg as well as the number of CRI sites was determined. The means for determination of each parameter are the same as those detailed in Table II.

required for $\mathrm{GP}_{\mathrm{ca}}$ formation. We are also investigating the ability of IgG antibodies (both cold- and warm-reacting) to induce membrane changes similar to those seen with the IgM anti-I.

To understand the etiology of the greater efficiency of binding of nascent $\mathrm{C} 3 \mathrm{~b}$ to CCAD erythrocytes, it is necessary to examine the biochemistry of both glycophorin- $\alpha$ and $\mathrm{C} 3$ activation and binding (13). Glycophorin- $\alpha$ is the major erythrocyte sialoglycoprotein (there are $\sim 1 \times 10^{6}$ copies/cell). The molecule is $60 \%$ carbohydrate by weight with 9 of the first 15 amino acids being $O$-glycosidically linked with oligosaccharides. C3 is composed of an alpha (127,000 D) and a beta $(75,000$ D) chain. Upon enzymatic activation, a 10,000 D fragment (C3a) is cleaved from the $\alpha$-chain. This alters the conformation of the molecule such that an internal thioester bond within the $\alpha$-chain is exposed. This exposed but intact thioester bond constitutes the labile-binding site of $\mathrm{C} 3 \mathrm{~b}$. It has a half-life measured in milliseconds and can either become inactive by undergoing hydrolysis in the fluid-phase or form an ester or imidoester bond with a nearby reactive surface. The biochemical/biophysical properties of the reactive surface influence the efficiency of binding of nascent $\mathrm{C} 3 \mathrm{~b}$ to that particular surface. Previous studies from this laboratory have demonstrated that for human erythrocytes, C3b binds predominately to glycophorin- $\alpha$ by forming an ester bond with free hydroxyl groups of the carbohydrate moiety of the molecule (13). It seems likely, then, that the formation of $\mathrm{GP}_{\mathrm{ca}}$ induces conformational changes in the glycophorin- $\alpha$ constituent of the $\mathrm{GP}_{\mathrm{ca}}$ complex such that its glycosyl residues are more readily available for interaction with the labile-binding site of $\mathrm{C} 3 \mathrm{~b}$, thereby accounting for the greater efficiency of binding of fluid-phase activated C3b to CCAD erythrocytes (Fig. 3). Alternatively (or in addition), the $\mathrm{CoFBb}$ complexes might have a greater affinity for CCAD erythrocytes, thereby accounting for the greater binding of nascent $\mathrm{C} 3 \mathrm{~b}$ as a result of activation closer to the cell surface. While there was no statistically significant quantitative difference in the binding of ${ }^{125} \mathrm{I}-\mathrm{CoFBb}$ complexes to CCAD erythrocytes compared with normals (data not shown), it is possible that the complexes have a higher affinity for these abnormal cells which is not defined by the methods employed for these binding studies (separating the bound from the unbound ligand by spinning the cells through a phthalate or mixture [5]).
The erythrocytes of paroxysmal nocturnal hemoglobinuria (PNH) also bind more C3b than normal erythrocytes when complement is activated (3), and this greater binding of $\mathrm{C} 3 \mathrm{~b}$ also appears to be related, at least in part, to an abnormality in glycophorin- $\alpha$ (13). However, PNH erythrocytes do not bind C $3 \mathrm{~b}$ more efficiently than normal erythrocytes (3). Rather, in this case, it appears that the abnormality in glycophorin- $\alpha$ modifies the enzyme substrate interactions of the cell-bound alternative pathway convertase such that the convertase has greater enzymatic activity when affixed to PNH erythrocytes (3).

The biochemical composition of the surface upon which the complexes of the complement sequence are organized has been shown to greatly influence the activity of the constituent components of the complexes (13). However, this appears to be the first report demonstrating that antibody and complement interactions with membrane glycoproteins can induce biophysical changes in the intrinsic properties of the membrane which modify subsequent interactions with complement. Whether the $\mathrm{C} 3 \mathrm{~b}$ which is bound to $\mathrm{GP}_{\mathrm{ca}}$ is itself functionally aberrant and whether $\mathbf{G P}_{\mathrm{ca}}$ formation modulates other abnormal interaction with complement remain to be determined.

All of the C3b which is bound to CCAD after fluid-phase activation is released by treatment with hydroxylamine (Fig. 4 , lane 5). This contrasts sharply with the situation involving the C3dg which is bound to CCAD erythrocytes under in vivo conditions. In this case, only a very minor portion of the bound molecules are released by treatment with hydroxylamine (Fig. $2 B$, lane 4). This suggests that the $C 3 b$ which becomes bound as a result of complement activation by cell-bound IgM cold agglutinin forms primarily hydroxylamine-insensitive imidoester bonds, while fluid-phase-activated C3b forms exclusively hydroxylamine-sensitive ester bonds. (Interestingly, C3b which is bound after activation by the membrane-associated C3 nephritic factor-stabilized alternative pathway convertase [using purified complement components] is predominately, though not exclusively, hydroxylamine sensitive [13]). Apparently, then, interactions of the anti-I with its antigenic determinants mediate the biochemical events which favor imidoester bond formation between $\mathrm{C} 3 \mathrm{~b}$ and glycophorin- $\alpha$. Alternatively (or in addition), C3b which is bound via ester bonds in vivo may be more readily lost from the cell surface during circulation. The differences in types of bonding of $\mathrm{C} 3 \mathrm{~b}$ to cell surfaces 
may be of physiological importance since we have previously demonstrated that factor $\mathrm{H}$ binding to $\mathrm{EC} 3 \mathrm{~b}$ is influenced by the mode of $\mathrm{C} 3$ activation employed to create the $\mathrm{C} 3 \mathrm{~b}$-bearing erythrocytes (5).

The erythrocytes of the four patients with CCAD have very low numbers of $C R 1$ sites as determined by binding studies using a monoclonal antibody to CR1 (Table II). The presence of cell-bound $\mathrm{C} 3 \mathrm{~b}$ (up to 30,000 molecules/cell) does not reduce the number of CR1 sites per cell (data not shown); nor does the presence of cell-bound C3dg (Table IV), and apparently neither does the process of $\mathrm{C} 3 \mathrm{~b}$ conversion to $\mathrm{C} 3 \mathrm{dg}$ (Table IV). Using this same antibody, we have noted low numbers of CR1 sites on the erythrocytes of patients with IgG-mediated warm antibody hemolytic anemia whose erythrocytes bear C3dg (18). Thus, in the case of hemolytic anemias, low CR1 sites appear to be an epiphenomenon associated with the activation and fixation of $\mathrm{C} 3$ to the erythrocyte membrane surface. However, the reduction of CR1 sites does not occur under the in vitro conditions employed in the experiments whose results are depicted in Table IV. Perhaps, the interactions of erythrocytes bearing C3 fragments with elements of the reticuloendothelial system which possess complement receptors (22-25) are required to reduce the numbers of erythrocyte CR1 sites.

The erythrocytes of CCAD are abnormally resistant to complement-mediated hemolysis by cold agglutinins $(26,27)$. This phenomenon has been attributed to inhibition of binding of the IgM antibody to CCAD erythrocytes as a result of steric hinderance by incomplete complement complexes $(26,27)$. The studies reported here suggest that alterations in the biochemical properties of intrinsic membrane glycoproteins by antibody and complement may also be important in pathophysiological manifestations of CCAD, particularly in relation to complement-mediated events.

\section{Acknowledgments}

The authors wish to thank Dr. H. R. Silberman and Dr. W. F. Rosse of Duke University Medical Center and Dr. J. B. Weinberg of the Durham Veterans Administration Hospital for providing blood samples from patients with CCAD, and Dr. Patricia J. Baker of the University of Washington for performing crossed immunoelectrophoresis. Helpful discussions with Dr. Gordon D. Ross of the University of North Carolina at Chapel Hill are gratefully acknowledged. We also wish to thank Mrs. Sara Bostley and Ms. Karen Scheideler for help with preparation of the manuscript.

This work was supported by grant 1 R01 31379-01 from the National Institutes of Health.

\section{References}

1. Packman, C. H., and J. P. Leddy. 1983. Cryopathic homolytic syndromes. In Hematology. W. J. Williams, E. Beutler, A. J. Erslev, and M. A. Lichtman, editors. McGraw-Hill Book Co., New York. Third ed. 642-647.
2. Pruzanski, W., and K. H. Shumak. 1977. Biologic activity of cold-reacting autoantibodies. N. Engl. J. Med. 297:538-542, 583-589.

3. Parker, C. J., P. J. Baker, and W. F. Rosse. 1982. Increased enzymatic activity of the alternative pathway convertase when bound to the erythrocytes of paroxysmal nocturnal hemoglobinuria. J. Clin. Invest. 69:337-346.

4. Rosse, W. F., G. L. Logue, J. Adams, and J. H. Crookston. 1974. Mechanisms of immune lysis of the red cells in hereditary erythroblastic multinuclearity with a positive acidified serum test and paroxysmal nocturnal hemoglobinuria. J. Clin. Invest. 53:31-43.

5. Parker, C. J., P. J. Baker, and W. F. Rosse. 1983. Comparison of binding characteristics of factors $B$ and $H$ to $C 3 b$ on normal and paroxysmal nocturnal hemoglobinuria erythrocytes. J. Immunol. 131:2484-2489.

6. Lachmann, P. J., R. G. Oldroyd, C. Milstein, and B. W. Wright. 1980. Three rat monoclonal antibodies to human C3. Immunology. 41:503-515.

7. Lachmann, P. J., M. K. Pangburn, and R. G. Oldroyd. 1982. Breakdown of $\mathrm{C} 3$ after complement activation. Identification of a new fragment, $\mathrm{C} 3 \mathrm{~g}$, using monoclonal antibodies. J. Exp. Med. 156:205216.

8. Ross, G. D., J. D. Lambris, J. A. Cain, and S. L. Newman. 1982. Generation of three different fragments of bound C3 with purified factor I or serum. I. Requirements for factors $H$ vs. CRI cofactor activity. J. Immunol. 129:2051-2060.

9. Ross, G. D., S. L. Newman, J. D. Lambris, J. E. Devery-Pocius, J. A. Cain, and P. J. Lachman. 1983. Generation of three different fragments of bound C3 with purified factor I or serum. II. Location of binding sites in the $\mathrm{C} 3$ fragments for factors $\mathrm{B}$ and $\mathrm{H}$, complement receptors, and bovine conglutinin. J. Exp. Med. 158:334-352.

10. Hogg, N., G. D. Ross, D. B. Jones, M. Slusarenki, M. J. Walport, and P. J. Lachman. 1984. Identification of an anti-monocyte monoclonal antibody that is specific for membrane complement receptor type one (CR 1). Eur. J. Immunol. In Press.

11. Telen, M. J., T. J. Palker, R. M. Scearce, and B. F. Haynes. 1983. Identification of two high molecular weight erythrocyte membrane proteins which react with anti-glycophorin antibodies. Blood. 62:35a. (Abstr.)

12. Markwell, M. A. K., and C. F. Fox. 1978. Surface-specific iodination of membrane proteins of viruses and eucaryotic cells using 1,3,4,6-tetra-chloro-3 $\alpha, 6 \alpha$ diphenylglycoluril. Biochemistry. 6:21952202.

13. Parker, C. J., C. M. Soldato, and W. F. Rosse. 1984. Abnormality of glycophorin- $\alpha$ on paroxysmal nocturnal hemoglobinuria erythrocytes. J. Clin. Invest. 73:1130-1143.

14. Law, S. K., and R. P. Levine. 1977. Interaction between the third complement protein and cell surface macromolecules. Proc. Natl. Acad. Sci. USA. 74:2701-2705.

15. Law, S. K., N. A. Lichtenberg, F. H. Holcombe, and R. R. Levine. 1980. Interactions between the labile binding sites of the fourth (C4) and fifth (C5) human complement proteins and erythrocyte cell membranes. J. Immunol. 125:634-639.

16. Towbin, H., T. Staehelin, and J. Gordon. 1979. Electrophoretic transfer of proteins from polyacrylamide gels to nitrocellulose sheets: procedures and some applications. Proc. Natl. Acad. Sci. USA. 76:43504354.

17. Lachmann, P. J., D. Voak, R. G. Oldroyd, and D. M. Bevan. 1983. Use of monoclonal anti-C3 antibodies to characterize the fragments of C3 that are found on erythrocytes. Vox Sang. 45:367-372.

18. Ross, G. D., M. J. Walport, C. J. Parker, A. F. Lentine, C. R. 
Fuller, W. J. Yount, B. L. Myones, J. B. Winfield, and P. J. Lachman. 1984. Consumption of erythrocyte $C R 1$ in systemic lupus erythematosus and other diseases involving autoantibodies and complement activation. Clin. Res. 32:539A. (Abstr.)

19. Law, S. K., T. M. Minich, and R. P. Levine. 1981. Binding reaction between the third human complement protein and small molecules. Biochemistry. 20:7457-7463.

20. Law, S. K., N. A. Lichtenberg, and R. P. Levine. 1979. Evidence for an ester linkage between the labile binding site of $\mathrm{C} 3 \mathrm{~b}$ and receptive surfaces. J. Immunol. 123:1388-1394.

21. Capel, P. J. A., O. Groeneboer, G. Grosveld, and K. W. Pondman. 1978. The binding of activated $\mathrm{C} 3$ to polysaccharides and immunoglobulins. J. Immunol. 121:2566-2572.

22. Schreiber, A. D., and M. M. Frank. 1972. Role of antibody and complement in the immune clearance and destruction of erythrocytes. I. In vivo effects of IgG and IgM complement-fixing sites. $J$. Clin. Invest. 51:575-582.

23. Schreiber, A. D., and M. M. Frank. 1972. Role of antibody and complement in the immune clearance and destruction of erythrocytes. II. Molecular nature of IgG and IgM complement-fixing sites and effects of their interaction with serum. J. Clin. Invest. 51:583-589.

24. Jaffe, C. J., J. P. Atkinson, and M. M. Frank. 1976. The role of complement in the clearance of cold agglutinin-sensitized erythrocytes in man. J. Clin. Invest. 58:942-949.

25. Atkinson, J. P., and M. M. Frank. 1974. Studies on the in vivo effects of antibody. Interactions of IgM antibody and complement in the immune clearance and destruction of erythrocytes in man. J. Clin. Invest. 54:339-348.

26. Evans, R. S., E. Turner, and M. Bingham. 1967. Chronic hemolytic anemia due to cold agglutinins. The mechanisms of resistance of red cells to $C$ hemolysis by cold agglutinins. J. Clin. Invest. 46:14611474.

27. Evans, R. S., E. Turner, M. Bingham, and R. Woods. 1968. Chronic hemolytic anemia due to cold agglutinins. II. The role of $C$ in red cell destruction. J. Clin. Invest. 47:691-701. 